\title{
Nelson Werneck Sodré: um historiador militar no Iseb e a gênese da teoria da revolução brasileira
}

Nelson Werneck Sodré: a military historian in the Iseb and the origin of the theory of brazilian revolution

\section{Eder Renato de oliveira*}

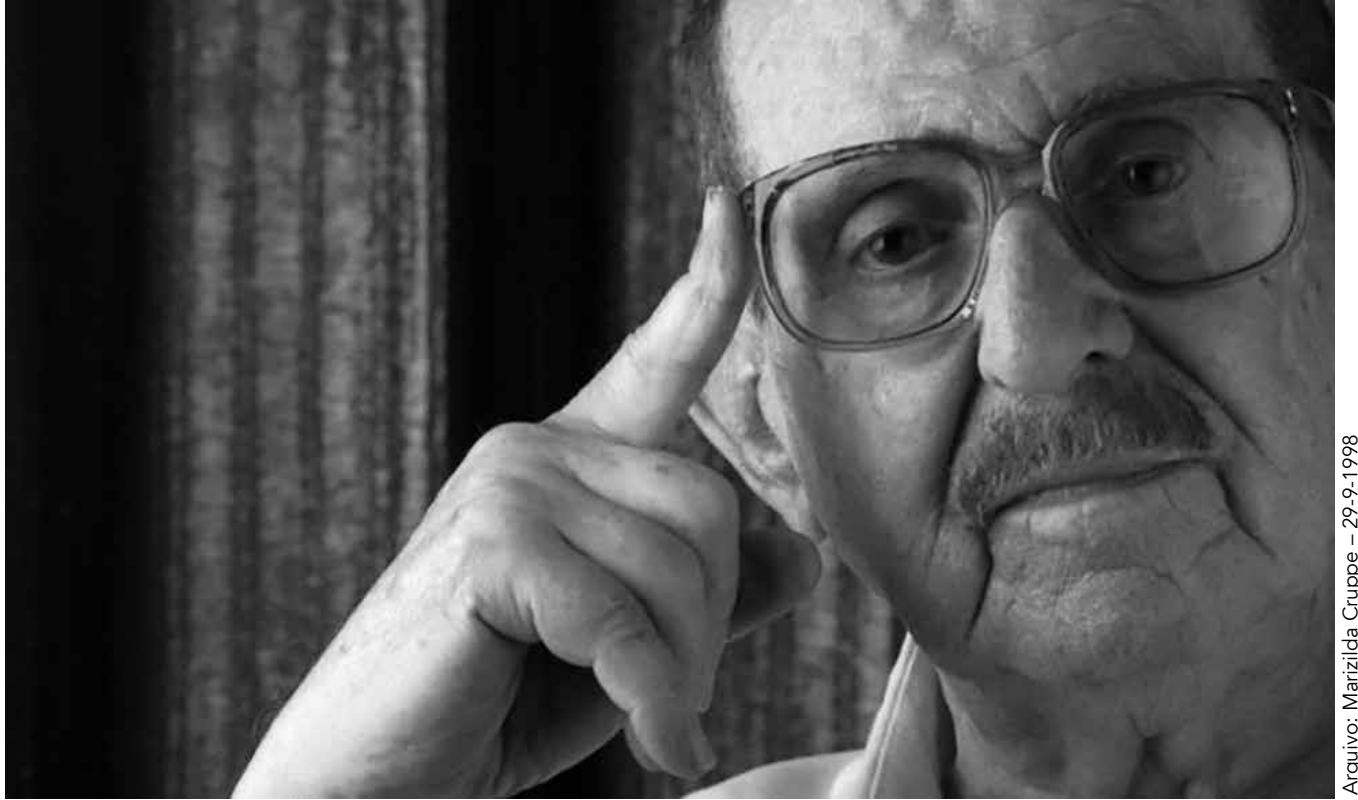

Nelson Werneck Sodré (1911-1999), militar, historiador marxista brasileiro 


\section{RESUMO}

O objetivo deste artigo é tornar públicos os resultados preliminares de investigações em andamento para tese de doutoramento em Ciências Sociais. Pretendemos examinar a concepção de revolução brasileira na obra do historiador e militar Nelson Werneck Sodré e o cerne de sua teoria sobre o Brasil quando de sua atuação política e intelectual no Instituto Superior de Estudos Brasileiros (Iseb). Localizar o núcleo da argumentação sodreana no Iseb lança luz às categorias ainda hoje mal interpretadas sobre a ideia de "mudança social" e "revolução democrático-burguesa": povo, nação, nacionalismo e revolução anti-imperialista, nacional e antifeudal. Os resultados, ainda que propedêuticos, foram obtidos com base não apenas nas leituras das obras fundamentais de Nelson Werneck Sodré, mas enfocando o cerne dessa produção: o Iseb. No contexto de um movimento de recuperação crítica, num reajustamento de foco, procuramos definir os elementos da teoria de Sodré, vulgarmente chamada de "teoria consagrada", e o produto de vertentes historiográficas apressadas, ainda que importantes para o debate, no julgamento da obra e da atuação do autor no Iseb.

Palavras-chave: Revolução brasileira. Nelson Werneck Sodré. Iseb.

\section{ABSTRACT}

The aim of this paper is to make public the preliminary results of an ongoing investigation for doctoral thesis in Social Sciences. We intend to discuss Nelson Werneck Sodré's concept of "Brazilian revolution", as well as the core of his theory on Brazil when politically and intellectually active inside the Higher Institute of Brazilian Studies (Iseb). To localize the nucleus of Sodreian argumentation is to shed light into categories connected to the ideas of "social change" and "bourgeois democratic-revolution", both poorly understood in the present day, which are: Nation, people, nationalism and the national, anti-feudal and anti-imperialistic revolution. The results, although introductory, were obtained not only by the study of Sodré's main works, but also analyzing the core of his production: the Iseb. Trying a critical recovery through a rearrangement of focus, we aim to define all the elements of Werneck Sodrés commonly known "consecrated theory" as well as the product of historiographical strands that were too hasty in judging both the work and the acting of the author inside Iseb.

Keywords: Brazilian revolution. Nelson Werneck Sodré. Iseb. 


\section{INTRODUÇ̃̃̃: A PERSPECTIVA TEÓRICA DO ESTUDO}

Importantes debates historiográficos se deram sobre o Instituto Superior de Estudos Brasileiros (Iseb) desde seu fechamento pelo golpe militar-burguês de 1964 . $\mathrm{Na}$ área das ciências sociais e filosofia, merece destaque o já clássico Iseb: fábrica de ideologias, do professor Caio Navarro de Toledo. Até o final da década de 1980, as ciências sociais tinham como objeto de pesquisa o tema da revolução brasileira, e, dessarte, as investigações sobre o Iseb foram alvo de debates; era necessário explicar o golpe e as instituições daquele pré-I964.

Evidenciamos que há uma ala na historiografia e nas ciências sociais brasileiras que sustenta que o debate sobre a revolução brasileira já foi superado e esgotado. Esse núcleo tem hoje seu centro irradiador nas Ciências Sociais da Universidade de São Paulo (USP), que, atualmente, tem como foco a análise dos mecanismos da democracia, já que esta, segundo José Álvaro Moisés, professor da referida universidade, já estaria consolidada no Brasil: "não mais pensamos na democracia ou no regime político estável que queremos. Já os temos. Trata-se agora de saber como a democracia funciona e que resultados podemos esperar de um governo democrático" (FERRARI, 20I4, p. 66). Como se lê em entrevista de Sérgio Adorno - também professor de Ciência Política na USP - à revista Pesquisa Fapesp,

nos anos 1970, todo o curso de Sociologia era montado para estudar o rumo da revolução burguesa no Brasil [...] nos dias de hoje, diz Adorno, ganha destaque uma linha de interpretação que não enfatiza tanto as estruturas, mas os atores; não só o modo de organização, mas as relações interativas também (FERRARI, 20I4, p. 66).

Pudemos averiguar com base em nossas primeiras leituras que esse debate ainda suscita certas tendências atuais de importância historiográfica - que só agora começam a ser reavaliadas. Dessa maneira, entendemos que há duas vertentes: a que acredita que o debate está encerrado, ou seja, aquela sociologia comprometida com a ordem das coisas - a "uspiana" —, que faz agora o debate apenas no âmbito da política e do Estado autocrático burguês (MAZZEO, 20I5), da análise e funcionamento da democracia, e outra sociologia, que acreditamos mais crítica, que não abre mão de discutir a questão da gênese, desenvolvimento e crise do capitalismo na formação social brasileira. E resta esclarecer ainda que duvidamos do caráter democrático que se "abriu" após I988. A realidade sociopolítica do Brasil pós-2013 e os recentes acontecimentos políticos que tocam a República com a onda neoconserva-

Caio Navarro de Toledo é graduado em Filosofia pela Universidade de São Paulo (USP) e defendeu na Universidade Estadual Paulista "Júlio de Mesquita Filho" (Unesp) sua tese de doutorado em Filosofia (1974), intitulada Ideologia do desenvolvimento: análise de uma instituição, que dá origem ao livro Iseb: fábrica de ideologias. O estudo de Navarro circunscreve-se à fase exordial do Iseb, mas ainda é um ponto de referência para refletir criticamente sobre o instituto, mesmo que não se esteja em total acordo com as proposições ali apresentadas. 
dora advinda do golpe de 2016 e a ascensão do ultradireitista Jair Messias Bolsonaro ao governo parecem desmentir a inócua formulação do cientista político José Álvaro Moisés².

A predominância dos estudos chamados isebianos pautara-se pelas investigações sobre a instituição "em si", de forma homogênea e não considerando os homens de carne e osso - para lembrar uma expressão do filósofo alemão Karl Marx. Não é possível - ao menos para uma ciência social crítica - o estudo, do ponto de vista da totalidade, das instituições como se nelas não atuassem indivíduos com suas pré-noções, ideologias e convicções políticas. Portanto, não concebemos o Iseb apenas como uma instituição, mas como uma organização de homens de carne e osso que pugnaram pelo desenvolvimento autônomo do Brasil como nação viável para os interesses dos brasileiros. Assim, partiremos dos homens realmente ativos, do seu processo de vida real, não daquilo que dizem, imaginam ou representam (MARX, 20Io).

Caio Navarro Toledo tem o mérito do pioneirismo não apenas ao escrever sobre o Iseb, mas também por situar cronologicamente os momentos daquele instituto. Os três momentos deste, elencados por Toledo, são: o momento nascente (I) que tem duração de poucos meses e vai da sua fundação até o momento em que Juscelino Kubitschek torna o Iseb parte integrante do Ministério da Educação (MEC) ${ }^{3}$. Os integrantes desse momento de nascedouro caracterizam-se por diversas concepções ideológicas em contradição. A maioria tinha uma visão antiestatista, sem "a menor referência ao nacionalismo como possível ideologia [...] do desenvolvimento industrial brasileiro; pelo contrário, [...] o antinacionalismo pode ser considerado como a posição ideológica comum a todos eles" (TOLEDO, I982, p. I87) ${ }^{4}$. Na fase subsequente (II), predominam as teses sobre o nacional-desenvolvimentismo. Essa fase coincide com o período do governo de JK. O momento derradeiro do Iseb (III) se insere no período das "reformas de base" do governo de João Goulart.

Apesar da "guinada" à esquerda do instituto no governo João Goulart, Angélica Lovatto - eminente estudiosa do Iseb - assevera que ainda não se tem clareza da posição político-ideológica dos isebianos naquela quadra histórica. Por isso, apesar dos esforços de intelectuais que já penetraram no Iseb como objeto a ser estudado, devemos recordar Christopher Hill quando ele indica que as questões da problemática histórica sempre surgem no tempo presente e à luz de novas perguntas. Dessarte,

\footnotetext{
2 A complexidade da processualidade da história recente do Brasil não nos permite avaliar contundentemente no âmbito de um artigo a realidade dos processos presentes. Aqui, como já mencionamos, apenas buscamos, a longo prazo, numa agenda extensa de pesquisa, compreender os nexos da teoria sodreana, em reajuste do foco histórico no Iseb.

O Iseb foi fundado oficialmente em 14 de julho de 1955 no interino governo de Café Filho. Anteriormente era denominado Instituto Brasileiro de Economia, Sociologia e Política (lbesp). O Ibesp surgiu da confluência de intelectuais de renome de São Paulo e Rio de Janeiro no município fluminense de Itatiaia, em 1952, durante o governo de Getúlio Vargas. Sodré não participou do "Grupo de Itatiaia". Sua admissão se deu em 1955. Do "Grupo de Itatiaia", apenas o intelectual paulista Roland Corbisier integrou-se ao Iseb. Cf. Pécaut (1990).

Nomes importantes da cultura brasileira fizeram parte do instituto nesse primeiro momento: Sérgio Buarque de Holanda, Gilberto Freyre, Roberto Campos e até o músico e compositor Heitor Villa-Lobos.
} 
Nelson Werneck Sodré pode ser considerado atuante em todos os períodos do Iseb5, e "podemos afirmar com certeza que as posições de Sodré eram aquelas que se localizavam no arco mais progressista daquele instituto" (LOVATTO, 2006, p. 3I6).

Adotamos neste artigo a periodização que caracteriza dois períodos: a fase dos isebianos históricos, que se coaduna com o período de estabilidade política e crescimento econômico do governo JK (I), e o período das "reformas de base" do governo de João Goulart (II) ${ }^{6}$. Considera-se dizer ainda que nos situamos sob a perspectiva dos estudos históricos sobre o Iseb que buscam analisar a concretude e as particularidades do todo, ou seja, a unidade da diversidade (MARX, 2008). Contudo, prioriza-se a fase II, pois é nela que localizamos a fase mais produtiva da obra de Nelson Werneck Sodré. Para não restar dúvidas, queremos compreender a teoria da revolução brasileira de Sodré e lembrar que essa teoria foi criada, formulada e desenvolvida como fruto das aulas e conferências e da intensa atividade intelectual de Sodré.

Jean-François Sirinelli afirma que as malhas de sociabilidade criam "um pequeno mundo estreito" em que a solidariedade social, em sentido sociológico, se estreita em ambientes diversos, que podem ser um instituto, uma universidade, conselhos editoriais, partidos ou sindicatos, e que possibilitam a intelectuais entrelaçar mutuamente perspectivas teóricas (SIRINELLI, 2003). Segundo Daniela Conte, "no caso de Nelson Werneck Sodré, a principal rede de sociabilidade era o Instituto Superior de Estudos Brasileiros" (CONTE, 20Io, p. 22). Depreende-se assim que, no Iseb, Sodré postulava uma similitude ideológica, transmitindo e recebendo influências das teses nacionalistas em conferências, aulas e publicações do instituto. Há claramente uma dialética em curso: tensões teóricas que se coadunavam e que negavam e superavam tendências históricas e teóricas daquele momento de revolução democrático-burguesa.

\section{O MILITAR HISTORIADOR E O HISTORIADOR MILITAR: APONTAMENTOS BIOGRÁFICOS}

Para situar o leitor, vamos fazer aqui uma breve explanação da vida de Nelson Werneck Sodré, que nasceu no ano de I9II no Rio de Janeiro e faleceu em I999, na cidade paulista de Itu. Sua família não tinha vínculos militares. Nela havia nomes como Odorico Mendes, que traduzira Homero e Virgílio, e o romancista Joaquim Manuel de Macedo. No entanto, ninguém melhor que o próprio Nelson Wer-

\footnotetext{
Interessante relato de Olga Sodré — filha de Nelson — sobre esse aspecto do início dos primeiros contatos entre Sodré e o Iseb: "O primeiro contato de Nelson Werneck Sodré com o lbesp ocorreu no primeiro trimestre de 1954, por intermédio do professor Guerreiro Ramos, que o convidou a integrar esse grupo e participar de suas atividades. Essa instituição foi responsável pela edição da revista Cadernos de Nosso Tempo, editada entre 1953 e 1956 e em torno da qual viria a se constituir o núcleo do futuro Iseb. No primeiro trimestre de 1954, quando passávamos as férias no Rio, como fazíamos todos os anos, desde que meu pai fora 'exilado' na fronteira do Rio Grande do Sul, ele conheceu o professor Guerreiro Ramos, que já lecionava na Ebap (FGV), onde eu viria a estudar de 1960 a 1964, ano em que me formei como bacharel em administração pública." (SODRÉ, 2011, p. 11)

6 Fizemos essa divisão didática porque, como chamou atenção Angélica Lovatto, pensar o Iseb como homogêneo "leva o leitor mais desavisado a entender o contato parcial com a obra isebiana como a totalidade identificadora do pensamento produzido naquele instituto" (LOVATTO, 2006, p. 318).
} 
neck Sodré, em suas Memórias de um escritor, para falar de si mesmo, num processo de imaginação sociológica - como postulou o sociólogo estadunidense Wright Mills (MILLS, I969):

Nasci em I9II; tinha 3 anos ao irromper a Primeira Guerra Mundial; 6, quando surgiu a Revolução de Outubro; 7, quando terminou a guerra; II, quando o Brasil completou um século de vida independente (sendo, entretanto, tão dependente ainda). Vivi o tempestuoso período entre a Primeira e Segunda Guerra Mundial, com todas as suas manifestações de renovação econômica, política, social, artística, e também as de desespero, a busca angustiada da originalidade em arte e a violenta luta pelo poder; vivi o mundo em que viveram o Kaiser Guilherme II, da Alemanha, o imperador Francisco José, da Áustria-Hungria, Clemenceau, Poincaré, Chamberlain, Lloyd George, o presidente Wilson, Sun Yat Sen, Lênin, para chegar à fase em que viveram Hitler, Mussolini, Roosevelt, Stálin. No Brasil, atravessei justamente o tempestuoso período do tenentismo, na agonia da República Oligárquica; do Modernismo, em literatura e nas artes; da Revolução de 1930, do movimento de 1932, do levante de 1935, da ditadura do Estado Novo, do putsch de 1938, da Segunda Guerra Mundial e da nossa participação nela; da reconstitucionalização e das lutas políticas subsequentes, com os golpes e tentativas de golpe de 1945, 1955, de I96I, de I964, da ditadura militar então instaurada (SODRÉ, I970, p. I5).

Seu pai era advogado em São Paulo. Mas Sodré foi enviado ao internato (como era comum à época) para estudar no Colégio Brasileiro, em Copacabana. Ainda criança, presenciou a revolta tenentista conhecida como Revolta dos I8 do Forte de Copacabana, em I922. Em 1924, Sodré matricula-se no Colégio Militar do Rio de Janeiro e inicia sua vida como escritor de ficção numa revista chamada A Aspiração. Nesse tempo, Sodré, pertencendo aos estratos médios urbanos, lê Tolstói, Dickens, Flaubert, Stendhal e outros nomes da literatura, o que já demonstra seu apego pelas questões literárias. Também toma contato com o incipiente marxismo brasileiro da década de I920, lendo, principalmente, Plekhanov e Lênin. Em I929, Sodré publica na revista Carioca (RJ) seu conto "Satânia" — diga-se de passagem, premiado em concurso. Em I93I, Sodré vai para a Escola Militar do Realengo e passa a participar — também como um dos diretores - das publicações da revista da escola (CUNHA, 2006).

Depois de passar por Itu e Jundiaí, em São Paulo, Sodré começa a escrever sistematicamente na grande imprensa (no jornal Correio Paulistano) e publica, pioneiramente, História da literatura brasileira: seus fundamentos econômicos, em I938, com o intuito de entender o processo literário com base no materialismo histórico. Sodré, então, volta ao Rio de Janeiro e passa a conviver com intelectuais como Oliveira Vianna, José Lins do Rego, Azevedo Amaral, Graciliano Ramos e o jornalista Samuel Wainer em encontros na histórica livraria José Olympio, local de reunião da intelectualidade carioca. Em I938, Sodré é enviado para Campo Grande (no então estado 
de Mato Grosso); nesse mesmo ano retorna a São Paulo e ajuda no ensino da escola preparatória à Escola Militar. Em I94I é promovido ao posto de capitão, quando é já um colaborador em jornais como O Estado de S. Paulo.

Após dois anos na Bahia, de 1942 a I944, Sodré dirige-se ao Rio de Janeiro para fazer o curso da Escola de Estado-Maior. Já major - patente considerada de oficial superior -, Sodré passa a lecionar História Militar nessa escola. Em 1949, é escolhido membro do Instituto de Geografia e História Militar. Havia um grande debate na década de 1950 sobre a questão nacional e do desenvolvimento, e as Forças Armadas tinham um papel bastante importante nesses diálogos. Assim, Sodré participa da chapa nacionalista, juntamente com Estillac Leal e Horta Barbosa, nas eleições para a chefia do Clube Militar. Esse clube exercia notória influência nos debates sobre os rumos que o Brasil havia de tomar em relação ao desenvolvimento econômico. Para termos uma noção balizada dessa época, o coronel Luís de Alencar Araripe, estudioso da obra de Sodré e membro do conselho editorial da Biblioteca do Exército, relata:

O Clube Militar, desde a República, promovia debates sobre questões nacionais, às vezes intensos e apaixonados, o que o levava a frequentes incursões na política [...]. Nelson Werneck Sodré resiste aos argumentos para integrar a chapa em que figuravam vários colegas comunistas, alguns deles integrantes da Antimil7, mas termina por capitular. A I7 de maio de 1950, Estillac Leal derrota o general Oswaldo Cordeiro de Farias, elegendo-se presidente do clube. Na chapa de Cordeiro figurava o então coronel Humberto de Alencar Castelo Branco. Com a eleição, Sodré abandona o abrigo seguro de instrutor da Escola de Estado Militar e enfrenta os riscos da rasa campanha, mergulhando nos embates nacionalistas do clube. Foi uma decisão fatal (ARARIPE, 2006, p. 70).

Isso custou caro a Sodré, que foi obrigado a ficar de plantão no Rio Grande do Sul. Em I955, já no Rio de Janeiro, e como tenente-coronel, Sodré apoiou Teixeira Lott na contraofensiva à tentativa frustrada de golpe em II de novembro. Os setores golpistas do Exército tentaram, então, transferir Sodré para o Pará, mas isso, felizmente, foi revogado.

Em 1956, Sodré é eleito um dos diretores da Biblioteca do Exército e inicia a docência no Iseb. Nesse período, Sodré já é tido como um autor consagrado e que sempre se posicionara ao lado das forças ditas nacionalistas. Em I955 apoiou o contragolpe de Lott, como já nos referimos acima; em I960 fez campanha presidencial para esse general - o qual ele muito admirava; e, na crise política de I96I, Sodré, agora no posto de coronel, a mais alta patente do Exército, amargou dias de clandestinidade, sofrendo inclusive prisão militar.

\footnotetext{
A Antimil — redução de antimilitarista — foi criada em 1929, antes do pleno do III Congresso do PCB, ocorrido no mesmo ano. Desde então muitos militares, inclusive os de alta patente, aderiram a essa organização. Segundo o cientista político Paulo Ribeiro da Cunha: "A apreensão histórica da Antimil está intimamente relacionada à intervenção dos partidos comunistas entre os militares." (CUNHA, 2020, p. 282) Nelson Werneck Sodré, segundo o cientista político, era um deles. Cf. também Cunha (2012).
} 
Passada a crise, foi transferido para Belém. Mas, em I96I, Sodré entra para a reserva, no posto de general. Em I962, passa a se dedicar somente aos estudos históricos e lança seu mais importante livro - Formação histórica do Brasil —, fruto de sua marcada atuação no âmbito do Iseb. Com o golpe de I964, é preso por 57 dias e responde, até I966, a inquéritos policiais militares (IPMs). Depois de 1968, Sodré colaborou com Moacir Félix - editor, intelectual e escritor - e Ênio da Silveira na Revista Civilização Brasileira, que se configurou como centro de resistência intelectual à repressão que se seguiu ao golpe militar-burguês que se instalou no país em abril de I964. Com o ato institucional n 5 (AI-5), em dezembro de 1968, Sodré sentirá os "anos de chumbo" e o consequente ataque às artes, às letras e à cultura. Mesmo assim, dá apoio à revista Temas de Ciências Humanas e passa a escrever nas revistas Encontros com a Civilização Brasileira e Memória \& História e no semanário Voz da Unidade (NETTO, 20II).

Na década de 1990, Sodré dedica-se à revisão e releitura de suas obras, publicando Capitalismo e revolução burguesa no Brasil (1990), na verdade, um livro de reafirmação teórica em que revitaliza suas teses e se mostra uma das vozes dissonantes da onda neoliberal em curso. Infelizmente, apenas no final da vida Sodré passa a ter sua obra reconhecida, participando de conferências acadêmicas.

Claro está que o historiador marxista Nelson Werneck Sodré, autor de 56 livros e intelectual de primeira ordem, deixou um imenso legado sobre a teoria da revolução brasileira, que foi relegada e ridicularizada por setores liberais e de esquerda após o golpe militar-burguês (1964). Em um movimento de resgate da obra de Sodré na virada do século XX, este artigo buscar adentrar nos pormenores da teoria sodreana que foi produzida, não esqueçamos, no Iseb, e que foi vulgarmente tachada de "teoria consagrada”, e, assim, reavaliá-la de forma crítica. Desatualizado, stalinista, marxista cristalizado, ortodoxo e linear foram alguns dos adjetivos investidos contra sua pessoa e sua obra. José Paulo Netto aconselha a superar os preconceitos e estudar rigorosamente a obra de Sodré, incluindo a produzida em seu período no Iseb. A hipótese teórico-metodológica que anima este trabalho almeja compreender o núcleo da argumentação sodreana: a teoria da revolução brasileira não foi fruto de uma leitura equivocada da realidade histórica do período, quando levamos em conta o conjunto da sua produção teórica e militante, dado que o país vivia um período de revolução democrático-burguesa. Sabemos das polêmicas que esse debate pode desencadear, mas é justamente o papel da academia: debater os temas sem preconceitos.

\section{A GÊNESE DA TEORIA DA REVOLUC̣̃̃O BRASILEIRA DE SODRÉ: UM HISTORIADOR REVOLUCIONÁRIO NO ISEB}

O desenvolvimento do debate teórico na historiografia e nas ciências sociais do pós-guerra suscitou polêmicas na intelectualidade acerca de temas como desenvolvimento, subdesenvolvimento, formação social e vias de transição para o capitalismo ou o socialismo. Na década de I950, os Estados Unidos da América despontavam como 


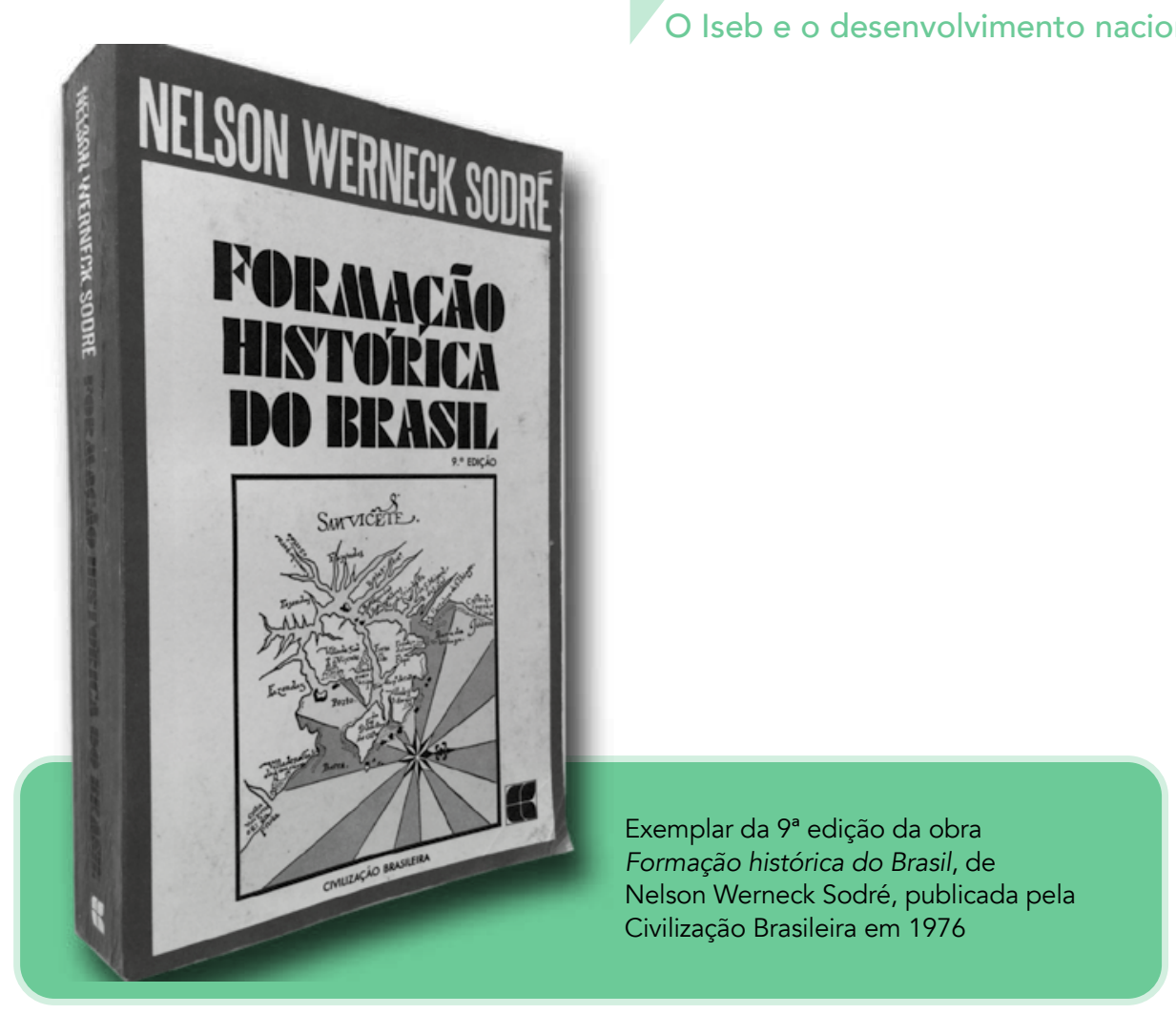

a maior potência capitalista, e a Europa ainda caminhava lentamente rumo à reconstrução econômica. Em face disso, historiadores importantes buscavam interpretar os rumos do desenvolvimento e, em maior ou menor grau, valeram-se das interpretações de Marx e Engels no que tange a temas como modo de produção, formações econômicas e causas da transição. Esse debate não apenas respingou no seio da intelectualidade brasileira mais avançada como suscitou uma ampla discussão em lugares e instituições como, por exemplo, o Iseb ${ }^{8}$, que teve Nelson Werneck Sodré como um de seus mais importantes teóricos no campo do marxismo9.

Obviamente, Sodré não foi o único intelectual marxista de peso no Iseb. Havia um grande esforço de desenvolver uma intelligentsia ${ }^{10}$ para pensar os rumos do país e dar ao Estado brasileiro soluções para o problema do subdesenvolvimento. Ignácio Rangel formularia a tese da dualidade básica, entre 1953 e I962. Nessa concepção, Rangel compreendia três fases da economia brasileira, que só poderia ser explicada pela tese da dualidade básica. A primeira fase teria se dado no período joanino (I808-I822) e caracterizava-se pelo escravismo (polo interno) e por formas mercantis do capitalismo (polo externo). A segunda fase dessa dualidade básica se daria pela crise do escravismo, responsável pela transformação das fazendas de café em polos de latifúndio

\footnotetext{
No âmbito da América Latina, a Comissão Econômica para a América Latina e o Caribe (Cepal) deu importantes contribuições em torno do tema do desenvolvimento.

9 José Carlos Reis, importante professor de Teoria da História da Universidade Federal de Minas Gerais (UFMG), entende ser Nelson Werneck Sodré "o teórico mais importante dos anos 1950, embora não fosse o único historiador marxista importante" (REIS, 2007, p. 147).

10 Em sua tese de doutorado, a cientista política Angélica Lovatto argumenta que "os autores se colocavam como verdadeira intelligentsia de uma elite nacional" (LOVATTO, 2010, p. 79).
} 


\section{No momento em que Ignácio Rangel, principal economista do Iseb, desenvolve a teoria do feudalismo - parte integrante da segunda fase da dualidade básica -, Sodré estava, também, a caminho de uma teoria de Brasil em que a ideia de feudalidade era parte integrante da sua teoria da revolução brasileira}

feudal. Esse é um ponto interessante. No momento em que Ignácio Rangel, principal economista do Iseb, desenvolve a teoria do feudalismo - parte integrante da segunda fase da dualidade básica - , Sodré estava, também, a caminho de uma teoria de Brasil em que a ideia de feudalidade era parte integrante da sua teoria da revolução brasileira. E, por fim, a terceira tese da dualidade básica de Ignácio Rangel identifica a crise capitalista de 1929 e a formação de um capitalismo industrial como fatores dessa dualidade. Sodré será, e defendemos isso aqui, profundamente influenciado por essa leitura da terceira dualidade ao defender a interpretação de que a revolução brasileira tem início com a Revolução de I930 (BIELSCHOWSKY, 20I4).

A revolução brasileira foi, ao longo de todo o século $\mathrm{XX}$, ao mesmo tempo uma categoria de análise da realidade histórico-social brasileira, principalmente na esquerda composta pelo $\mathrm{PCB}^{\mathrm{II}}$ na primeira metade do século, e o objetivo de um programa de ação sobre a realidade social e política. A despeito de ser uma criação do PCB nos anos I920, acabou por ser tema de inúmeros intérpretes que compõem todo o espectro político, de uma ponta à outra.

O tema da revolução brasileira enquadra-se naquilo que os sociólogos profissionais chamam de mudança social (JOHNSON, 1997). A ideia de revolução brasileira, assim como a de mudança social, engendrou diversas conotações teóricas e políticas. Destarte, diversos autores e organizações políticas e de Estado trabalharam com o tema da revolução brasileira desde seu surgimento no PCB até o golpe que depôs João Goulart ${ }^{12}$ : Octávio Brandão, Caio Prado Júnior, Jacob Gorender, Nelson Werneck Sodré, Alberto Passos Guimarães, PCB, Iseb, Celso Furtado, que escreveu a pré-revolução brasileira, e Hélio Jaguaribe, no Iseb (PERICÁS, 20I9).

\footnotetext{
11 No ano de 1922, o atual PCB era chamado de Partido Comunista do Brasil — Seção Brasileira da Internacional Comunista, sob a sigla PCB. Em 1961, por questões estratégicas e táticas, o PCB modificou seu nome para Partido Comunista Brasileiro.

12 Sobre o governo João Goulart, ver Bandeira (2010).
} 


\section{Diversos autores e organizações políticas e de Estado trabalharam com o tema da revolução brasileira}

Nas décadas que se seguiram ao golpe burguês-militar, diversos analistas sociais debruçaram-se sobre as causas da derrota do movimento popular no processo de revolução democrático-burguesa. Profusas foram as interpretações que buscaram tanto explicar essas causas como também identificar aquelas teorias que davam substrato às formulações do PCB, da Cepal e do Iseb.

Nos anos que se seguiram ao segundo lustro dos anos 1950, Sodré, afinado com o debate em torno dessas questões candentes, desenvolverá uma teoria do Brasil singular e que envolve problemas até hoje não resolvidos nas ciências sociais brasileiras: as questões do feudalismo, da transição, da democracia e do caráter de nossa formação, tanto em termos econômicos quanto sociais e culturais. A teoria de Brasil que Sodré desenvolverá ao largo de décadas de incansável estudo contém elementos problemáticos e, ao mesmo tempo, luminosos para o entendimento da realidade histórica brasileira.

Em face disso, intelectuais como Ruy Mauro Marini, Florestan Fernandes, José Chasin, Fernando Henrique Cardoso, Francisco de Oliveira, Fernando Novaes - os dois últimos, do Centro Brasileiro de Análise e Planejamento (Cebrap) - e Carlos Guilherme Mota, da USP, além de entidades como a Organização Revolucionária Marxista Política Operária (Polop), tentaram, de uma forma ou outra, não apenas culpabilizar o PCB e as proposições nacionalistas do Iseb pelo golpe como também desqualificar as teses daquele que foi, no pré-golpe, o mais destacado analista da revolução brasileira: Nelson Werneck Sodré (DEL ROIO, 20I6b).

As obras Introdução à revolução brasileira, fruto de cursos que Sodré dava quando de sua atuação como professor de História do Brasil no Iseb, e, de forma mais marcada, Formação histórica do Brasil, trazem para o centro do debate a questão histórica acerca de como se deu a formação social brasileira. Perscrutam, com base nos pressupostos da teoria social marxista, a formação do Brasil. Trata-se de obras em que Sodré revisa suas teses contidas em Formação da sociedade brasileira (1944). Sodré olha do presente para o passado no intuito de construir uma teoria do Brasil que dê conta das particularidades do processo em curso, a que ele chama revolução brasileira (SODRÉ,I958).

Essa produção teórica não se deu como mero contato de Sodré com os círculos intelectuais do Iseb: ele vinha amadurecendo suas teses desde o início da década de 1950. Por isso, é importante evidenciar um ponto da trajetória biográfica de Sodré que já tangenciamos acima: a sua participação política no Clube Militar. A questão nacional, no Brasil, teve diversas nuanças. Para o brazilianista Thomas Skidmore, os militares tiveram grande influência nos debates que se seguiram à posse de Getúlio Vargas. Se no início de seu governo ainda não estavam muito nítidos os caminhos do nacionalismo, 
após os eventos na eleição do Clube Militar de 1950 e a malograda tentativa de Getúlio de cooptar os setores udenistas, a questão nacional se aguça e os contornos políticos ficam mais claros. De um lado, havia os militares próximos dos ideais liberais e, de outro, os nacionalistas. Estes se dividiam em dois grupos, ambos nacional-desenvolvimentistas: os que não se opunham ao afluxo de investimentos estrangeiros para desenvolver a economia (principalmente nos pontos de estragulamento econômico, como o setor energético e o de transportes), e os nacionalistas de esquerda, que eram ferrenhos críticos da participação do capital estrangeiro na economia brasileira (SKIDMORE, I979).

José Paulo Netto nos lembrou de que a eleição do Clube Militar não era uma eleição qualquer. Inscrevia-se na polarização da Guerra Fria, "ao fim do governo antipopular e antinacional de Dutra" (NETTO, 20II, p. 28). Claro está que o certame no Clube Militar era um reflexo das contradições no campo militar. As duas chapas concorrentes, a do general nacionalista Estillac Leal e de Júlio Caetano Horta Barbosa e a dos generais conservadores Osvaldo Cordeiro de Farias e Emílio Rodrigues Ribas, entraram em rota de colisão que dividiu as opiniões no meio militar. A vitória da chapa nacionalista mostrou a Sodré suas consequências, e ele percebeu que estava na mira dos generais golpistas: foi transferido, como represália, para Cruz Alta (RS) em 195I. A partir daí os setores mais retrógrados da sociedade brasileira - empresários mais ligados à importação, a União Democrática Nacional (UDN) e generais como Alcides Gonçalves, Etchegoyen e Nelson de Melo - começaram uma verdadeira "cruzada democrática", num ambiente de violência e chantagem e com a propositada "neutralidade" de Getúlio Vargas (NETTO, 20II).

A outra experiência decisiva de Sodré foi a sua atuação no Iseb e a enorme influência que esse instituto teria na sua teoria de Brasil. Atesta esse nosso entendimento o estudo da cientista política Angélica Lovatto sobre a coleção "Cadernos do Povo Brasileiro", na qual Sodré escreveu Quem é o povo no Brasil?, sob a direção de importantes intelectuais como Álvaro Vieira Pinto e o editor Ênio Silveira. O próprio Álvaro Vieira Pinto escreveu um dos volumes, intitulado Por que os ricos não fazem greve? (LOVATTO, 20Io). Sodré era um membro ativo no Iseb, segundo João Alberto da Costa Pinto:

O essencial do pensamento e da intervenção política do historiador carioca dá-se com a produção acontecida na conjuntura de 1958-I964, quando, como professor do Instituto Superior de Estudos Brasileiros (Iseb), revisa (e em parte abandona) conceitualmente a sua produção anterior (PINTO, 20II, p. I69).

A revolução democrático-burguesa em curso no Brasil não dependia exclusivamente daquilo que Sodré chamou de burguesia nacional. Não obstante, Sodré superestimou a burguesia como classe nacional no curso da revolução democrática, e o golpe militar-burguês veio demonstrar o equívoco dele. No entanto, Sodré consegue compreender a "particularidade da formação histórica da nossa sociedade" (NETTO, 20II, p. 69) ao escrever a obra História da burguesia brasileira, em I964. Era óbvio para Sodré que a economia brasileira era parte integrante do incipiente sistema capitalista já nos primórdios da colônia. Contudo, Sodré identifica no final do século XVII uma 
regressão feudal que adentra a Primeira República. Isso daria uma nova conformação à burguesia brasileira, que, ao contrário das suas consortes, não surge como produto da subsunção dos meios de produção. É, portanto, uma burguesa débil, que se forma como dependente das burguesias inglesa e estadunidense.

Na década de 1950 e início dos anos 1960, a burguesia brasileira estava diante de um dilema: ou se alia ao latifúndio e se exime de uma potencial revolução socialista ou "prefere enfrentar essa ameaça, abre-se ao futuro, e se livra do latifúndio" (REIS, 2007, p. I65). Sodré fazia uma leitura conjuntural análoga à que Lênin e Trótski fizeram: qual a natureza da Revolução de 1905 na Rússia? A leitura menchevique previa uma revolução democrática e burguesa em que as forças sociais em disputa — burguesia, classe operária e campesinato - estariam sob a hegemonia da burguesia e seriam dirigidos por ela (MIRANDA; FERNANDES, 198I). Ora, Sodré não faz essa leitura de tipo menchevique. Ele não imaginava que o Brasil se tornaria uns Estados Unidos, tal como os mencheviques acreditavam que a Rússia se tornaria uma Alemanha. Para os bolcheviques a revolução é, sim, democrática e burguesa. Porém, para Lênin, assim como para Sodré, a revolução é um projeto em disputa, e a classe operária pode e deve dirigir o processo. Apesar de Sodré superestimar a atuação da burguesia nacional, ele não a via como a classe, por excelência, a conduzir o processo histórico de revolução, e via, sim, contradições entre burguesia e proletariado:

A contradição entre burguesia e o proletariado, assim, tem uma importância indiscutível para a luta de que o Brasil é teatro e para o conjunto de transformações que já foi consagrado como constituindo a revolução brasileira (SODRÉ, 1964, p. 395).

Claro está que a interpretação caiopradiana de que as teses de Sodré seriam produto do VI Congresso da Internacional Comunista, em I928, e que "reiterava a formulação esquemática e simplista das resoluções da Internacional Comunista para os países ditos independentes" (RECKZIEGEL, 2004, p. 326), não tem paralelo com a teoria sodreana de revolução brasileira, pois em nenhum momento de sua obra Sodré aventou a suposição de que o Brasil teria de passar, necessariamente, por etapas. O uso do substantivo etapa na obra de Sodré foi interpretado semanticamente e lexicalmente fora de contexto, pois não se assenta como imperativo categórico. Pelo contrário, o conceito de regressão feudal e o de contemporaneidade do não coetâneo mostram que não há linearidade na concepção histórica de Nelson Werneck Sodré.

\section{O PERCURSO DA FORMAÇ̃̃ SOCIAL E HISTÓRICA BRASILEIRA}

Para Sodré, Portugal não se constituiu capitalista na Revolução de Avis (13831385), pois esta não fora uma revolução burguesa de fato ${ }^{13}$. A Revolução de Avis foi

13 A ideia de que Portugal constituiu-se capitalista no contexto do início do ciclo português da expansão marítima tem como defensor, no Brasil, a figura de Roberto Simonsen, quando da publicação de sua História econômica do Brasil. 
uma etapa da centralização política nas mãos da nobreza. Ademais, o grupo mercantil liderado pela Coroa portuguesa não era identificado como classe burguesa, e havia uma aristocracia militar que redistribuía a terra.

Sodré identifica, então, um paradoxo na história de Portugal e na expansão ultramarina: o de que a amplificação territorial de Portugal (tanto de seu território interno como pelo estabelecimento de territórios além-mar) gerou um fortalecimento dos laços de servidão e consequente enfraquecimento do grupo mercantil. Por conseguinte, Sodré chega à seguinte conclusão: se Portugal era um reino de tipo feudal, como poderia ser o Brasil, sua colônia, mercantilista ou capitalista? Vemos aqui uma inflexão teórica: Sodré abandona a tese capitalista contida em sua obra Formação da sociedade brasileira, de 1944, que tinha, justamente, Caio Prado Júnior como inspiração.

Jorge Grespan lembra o peso que pode ter exercido a famosa "Declaração de março de 1958 ", do $\mathrm{PCB}^{14}$. No entanto, apesar de Sodré compor o partido, não vemos uma correlação direta que possa comprovar a vinculação da teoria dele com aquela declaração. Para tanto, seria necessário um estudo de fontes históricas primárias, que ainda não encontramos. Observa-se que Sodré trabalha com o universo categorial marxista de modo produção ${ }^{15}$ : por intermédio dessa categoria, Sodré sustenta que há uma evidente diferença entre capitalismo e capital comercial. No capitalismo, o excedente econômico, diz Sodré, tem base na produção de mercadorias, e o comércio é o elemento subordinado e determinado pela esfera da produção. No capital comercial, o excedente econômico é proveniente da troca de mercadorias, antes da consubstanciação do trabalho assalariado.

Por isso, o capitalismo surge de um processo endógeno. Portugal não era capitalista, portanto não implantou o capitalismo de fora para dentro, em razão de que não havia condições para tal. Quer dizer, não são as condições externas que determinam o capitalismo; não é do capital mercantil que deriva o capitalismo, de forma necessária. O Brasil, durante o chamado período colonial, teria sido dirigido e controlado por grupos mercantis ligados à Coroa (que para Sodré era constituída de uma nobreza feudal). Nas palavras de Sodré:

\footnotetext{
14 Estudos importantes foram feitos sobre o PCB ao longo das últimas décadas. Um estudo sobre as relações entre Iseb, PCB e ação sindical pode ser vista em Martins (1965).

15 No prefácio à obra Formações econômicas pré-capitalistas, o historiador inglês Eric Hobsbawm faz uma interessante análise sobre a problemática dos modos de produção em Marx. Preliminarmente, é possível dizer que Marx e Engels liam as principais publicações sobre o feudalismo, principalmente dos historiadores alemães Hansen, Meitzen e Maurer. Hobsbawm nos alerta para o parco conhecimento de Marx sobre o feudalismo (deficiência que ele mesmo admitia): "Só depois da publicação do volume I de O Capital (i.e., quando já tinha elaborado o esboço básico dos volumes II e III) esse problema começou, ao que parece, a preocupar os dois amigos, sobretudo a partir de 1868, quando Marx iniciou, seriamente, o estudo de Maurer, cujos trabalhos ele e Engels, daí por diante, encararam como a base de seus conhecimentos nesse campo." (MARX, 1985, p. 25) Nos termos da proposta deste paper, não é possível ir além no extenso campo de debate sobre modos de produção. Obviamente que, à luz de estudos posteriores, em nível de tese, esse debate terá a acolhida necessária.
} 


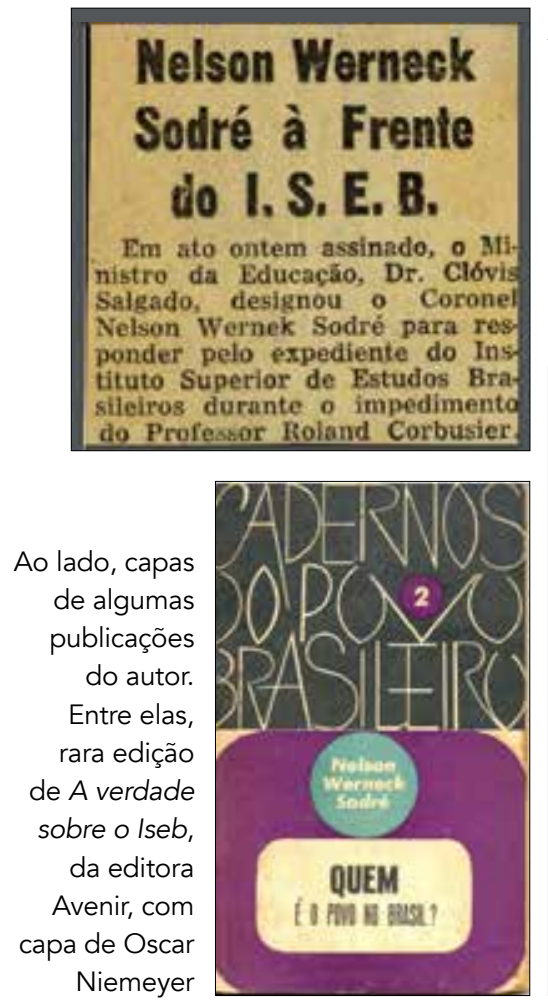

À esquerda, nota publicada no jornal Última Hora, de 9 de julho de 1958, informando sobre a designação de Nelson Werneck Sodré para responder pelo expediente do Instituto Superior de Estudos Brasileiros
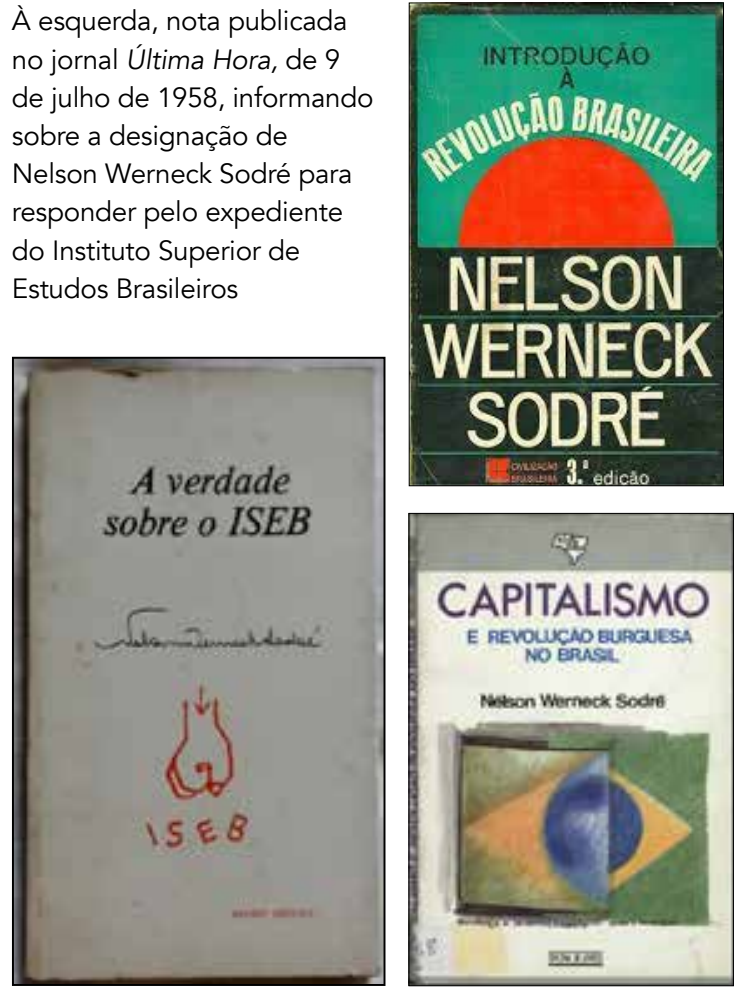

Grupo, ou camada social, embora importante, o dos mercadores não se definiu em classe, entretanto, nem alcançou as características que lhe permitissem o batismo de burguesia, que alguns historiadores lhe concedem, naquilo que o termo envolve de essencial. Nem chegou jamais a dominar o poder, influindo nele embora, particularmente nas fases de autonomia, e de expansão territorial, e de expansão navegadora (SODRÉ, 2002, p. 36).

\section{Continua Sodré:}

O processo de que surge o capitalismo é, pois, endógeno; ele surge de condições internas do país ou região em que se implanta; [...] um país ou região, assim, só consegue atingir a fase capitalista de produção quando:

- dispõe de uma massa de trabalhadores assalariados sem posses, pessoalmente livres, mas privados dos meios de produção e de subsistência, obrigados por isso a trabalhar mediante salário para o capitalista;

- dispõe de uma acumulação de riqueza em dinheiro necessária à criação das grandes empresas capitalistas (SODRÉ, 2002, p. 48-50).

Assim, o capitalismo não tinha vaga no Brasil do século XVI. Se for verdade que dava seus primeiros passos em países como a Holanda e, principalmente, a Inglaterra, em Portugal não havia uma classe burguesa em essência, argumenta Sodré. 
Apesar dos vultosos investimentos que foram necessários à empresa colonialista, os grupos mercantis foram dirigidos pela Coroa. Segundo Sodré: "A empresa das navegações, que possibilita as descobertas de que decorre a colonização, tem suas bases no capital comercial cujo aparecimento e desenvolvimento caracterizam o declínio do feudalismo." (SODRÉ, 2002, p. 6I)

Além disso, Sodré, ao inquirir quem realiza o investimento inicial à obra das Grandes Navegações (as do início do século XVI, não as anteriores - que começaram em I415, com a conquista de Ceuta, no norte do continente africano), responde que não são os grupos mercantis, pois estes "já não têm recursos para isso, nem interesse pela sua aplicação" (SODRÉ, 2002, p. 8I). Para Sodré, "está perfeitamente esclarecido que os primeiros colonizadores eram elementos da pequena nobreza, quando muito, nobres de títulos; elementos ligados à Coroa" (SODRÉ, 2002, p. 8I).

Esses primeiros colonos enfrentariam muitas dificuldades, como o problema da mão de obra, a luta contra os indígenas, a ocupação do vasto e inóspito território, a falta de recursos: "o modo de produção diverso está no fundo do antagonismo entre o indígena e o colonizador. Daí a dificuldade, em alguns casos a impossibilidade, de servir aquele como mão de obra, fornecendo o trabalho na empresa da colonização." (SODRÉ, 2002, p. 84) Assim, todo o conjunto de dificuldades advindas do investimento inicial "gera o modo escravista de produção" (SODRÉ, 2002, p. 85). "É a partir desse debate que Sodré assume parcialmente a tese do escravismo, proposta por Celso Furtado (1959), e, ao mesmo tempo, formula uma original visão sobre a formação social brasileira." (DEL ROIO, 20I6b, p. 88)

O escravismo ficou restrito, na visão de Sodré, às partes em que vigorou a unidade produtora típica do Brasil colonial, o engenho, e as atividades pastoris, ainda que vivendo, às vezes, como "vizinhas" do escravismo colonial ${ }^{16}$, conheceram, posteriormente, formas diferentes de relações sociais de produção da renda (SODRÉ, 199ob). Para entendermos mais adequadamente esse processo, Sodré sustenta que a expansão pastoril rumo ao interior do continente passou por três momentos: I) a vizinhança; 2) a coexistência, e 3) a separação entre as atividades agrícola e pastoril (SODRÉ, 199ob). Com isso o autor quer dizer que, paulatinamente, houve uma separação, uma divisão nas tarefas.

Nessas áreas pastoris, conheceram-se outras formas de relação social, o que o autor chamou de contemporaneidade do não coetâneo: "isto é, da existência, no mesmo tempo, de realidades sociais diferentes, mas no mesmo país ou colônia" (SODRÉ, 199ob, p. IO). Para sustentar essa tese, Sodré argumenta que a colonização teria sido ampla demais, e, em seus aspectos, veem-se outras formas de ocupação do território, outras formas de relação social de produção, portanto. Durante o processo de expansão territorial criaram-se diversas áreas de povoamento e de atividade econômica muito aquém da zona costeira: aquilo que Werneck Sodré chamou de "áreas secundárias de ocupação" — os vastos territórios de pecuária extensiva.

6 Essa é uma expressão pioneira de Sodré e não do dirigente e historiador marxista Jacob Gorender, autor de $\bigcirc$ escravismo colonial. Ver Gorender (1978). 
Numa tentativa de atualização do problema dos modos de produção, temos de estar cônscios de que na década de 1950 essa problemática não era nada exótica. $\mathrm{O}$ debate acerca dos modos de produção no Brasil inseria-se num contexto em que havia enorme necessidade ideopolítica de destacar como seriam os rumos do desenvolvimento econômico brasileiro e o tipo de revolução a ser realizada. Tal discussão tem origem na Europa do pós-Segunda Guerra - quando havia a necessidade de situar os problemas do capitalismo num continente arrasado pela guerra. Concorreram inicialmente para o debate os historiadores Paul Sweezy e Maurice Dobb ${ }^{17}$. Estava, a partir daí, aberto um campo de debates em que entraram posteriormente o historiador japonês Kohachiro Takahashi e os ingleses Christopher Hill, Perry Anderson e Rodney Hilton. Ou seja, Sodré estava "afinado" com os historiadores e a historiografia do seu tempo - compreendendo os rumos que o desenvolvimento ${ }^{18}$ do capitalismo teria e discutindo-os.

De forma geral, em particular no plano econômico, havia na década de 1950 uma pergunta crucial a que os setores mais esclarecidos e progressistas da esquerda e, em especial, o PCB, precisavam responder: deve-se apoiar o desenvolvimento capitalista ou seguir uma orientação de revolução aberta para chegar ao socialismo? A postura de Sodré diante dessa questão foi a de procurar uma interpretação da realidade brasileira baseada na concepção de história em Karl Marx: a resultante histórica do presente (do aqui e do agora) é fruto de um longo e complexo processo histórico de contradições entre forças produtivas e relações de produção, entre explorados e exploradores (MARX; ENGELS, 20IO).

Sodré buscou, então, desenvolver uma interpretação de Brasil com base nas raízes históricas do passado colonial, afirmando que os entraves à revolução brasileira eram os restos feudais. Consequentemente, a necessidade de se opor ao "bloco feudal-burguês" constituía uma das contradições fundamentais do Brasil da década de I950. Em suma, nessa interpretação do passado colonial, Sodré foge a esquemas geopolíticos e jurídico-territoriais que configuram o modo de produção como o mesmo em todo o território de jurisdição. Ao contrário, Sodré evidencia as particularidades no todo, "realidade na qual a lógica histórico-universal se reproduz, mas dentro de uma particularidade concreta" (DEL ROIO, 20I6b, p. 93).

Em 1966 veio a público uma obra importante de Caio Prado Júnior: A revolução brasileira, que teve, segundo a biografia mais completa até o momento escrita sobre o autor - a do historiador Luiz Bernardo Pericás —, "grande repercussão no país e alguma no exterior [...; um dos livros que fizeram a cabeça dos militantes da época"

\footnotetext{
17 "Para autores como Dobb, Hilton e, também, Sodré, Marx não desprezou em sua análise o efeito corrosivo do aumento da circulação monetária sobre a economia feudal, nem o papel da acumulação de capital mercantil na formação das pré-condições do capitalismo." (SILVA, 2006, p. 106)

18 No Iseb, o conceito de desenvolvimento não era uníssono. Os membros atuantes tinham suas próprias convicções teóricas acerca de desenvolvimento e desenvolvimentismo. Segundo Luiz Carlos BresserPereira: "No pensamento do Iseb havia um conceito de desenvolvimento que tomava emprestadas ideias de Marx, de Schumpeter e do estruturalismo latino-americano de Raúl Prebisch e Celso Furtado, sem, entretanto, se preocupar em ser fiel a qualquer uma dessas visões." (BRESSER-PEREIRA, 2004, p. 55) Obviamente, Nelson Werneck Sodré estava ancorado na perspectiva de Marx.
} 


\section{Sodré faz parte da tentativa de conhecer o Brasil pela ótica do desenvolvimento e da autonomia nacional}

(PERICÁS, 20I6, p. 206-207). O objetivo de Caio Prado Júnior era fazer uma análise "crítica" das concepções de revolução brasileira do PCB e de seu "teórico" Sodré: rebater a tese da existência de uma suposta burguesia nacional e a chamada "tese feudal" - e, por conseguinte, contestar a presença dos "restos feudais". Também reafirma a tese de historiadores como Roberto Simonsen de que a empresa da colonização tenha sido de natureza capitalista. Ora, como vimos acima, Sodré rebate com argumentos sólidos essa tese em Formação Histórica do Brasil. No entanto, segundo Caio Prado Júnior,

é isso que fizeram e ainda fazem certos pseudomarxistas, sem ao menos se darem conta disso, quando prefixam para todo e qualquer país uma etapa feudal, que existiu na Europa precedendo o capitalismo, e de que esse capitalismo resultou ou a que sucedeu. [...] Presumiu-se, desde logo, e sem maior indagação que, no Brasil, o capitalismo foi precedido de uma fase feudal, e que os restos dessa fase ainda se encontravam presentes na época atual. [...] O fato, contudo, é que o Brasil não apresenta nada que legitimamente se possa conceituar como "restos feudais". Não fosse por outro motivo, pelo menos porque, para haver "restos feudais", haveria por força de preexistir a eles um sistema "feudal" de que esses restos seriam as sobras remanescentes. Ora, um tal sistema feudal, semifeudal ou mesmo simplesmente aparentado ao feudalismo em sua acepção própria nunca existiu entre nós, e por mais que se esquadrinhe a história brasileira, nela não é encontrado (PRADO JÚNIOR, 20I2, p. 43, 5I).

Caio Prado Júnior, nessa obra, num esforço interpretativo sobre o que foi o golpe, faz crítica feroz às esquerdas e à sua tática de revolução brasileira. O erro fundamental da esquerda, segundo sua concepção, foi ter buscado uma característica para o conceito de revolução. Socialista ou democrática? Burguesa ou outra qualquer? (PRADO JÚNIOR, 20I2). Deve-se observar ainda que é o próprio Caio Prado Júnior que supõe a existência, inclusive de maneira implícita, de uma evolução linear de modos de produção. Nem mesmo Marx admitira uma existência linear e que obedecesse a critérios rígidos e teleológicos na história.

No prefácio a Formações econômicas pré-capitalistas, Hobsbawm diz: "não há, em Marx, nenhuma indicação que nos autorize a buscar alguma 'lei geral' de desenvolvimento que possa explicar sua tendência para evoluir no sentido do capitalismo" (MARX, I985, p. 44). Ou seja, Caio Prado identifica em Sodré as teses esquemáticas de Stálin. Ao que nos parece, tal operação carece de lógica interna, na medida em que Sodré fala de regressão feudal, dando a ideia clara de que o desenvolvimento próprio da 
história não segue rigidamente uma "marcha". Como claramente salientou João Quartim de Moraes, o economicismo de Caio Prado considera a evolução histórica uma "facticidade unidimensional" e não evidencia as tensões e contradições latentes, "para se ater à morna constatação do positivamente dado" (MORAES, 2007, p. 196).

Para Caio Prado Júnior, é módico apontar, antes mesmo do surgimento da realidade objetiva, qual o paradigma de revolução. O autor argumenta que o conhecimento objetivo da realidade abarca conhecer o que está sucedendo como processo e não o ser em si (PRADO JÚNIOR, 20I2). Caio Prado Júnior insiste em suas observações de ordem epistemológica: "É o que acontece que constitui o conhecimento científico; e não o que é" (CAIO PRADO, 20I2, p. 27). Está claro aqui que o autor chama a atenção para um fato: a revolução brasileira será (ou deveria ser) produto de uma correta interpretação conjuntural do presente e do processo histórico. Seria nisso que, de fato, consistiria uma "aplicação" correta do método dialético.

Estaria Caio Prado Júnior arremetendo contra as teses delineadas por Sodré ou criticando o programa do Partido Comunista, com sua caracterização de revolução brasileira (antifeudal, anti-imperialista, nacional e democrática), escrito após a "Declaração de março de 1958"? Na diligência de responder a essa questão, não achamos (ainda) nada de expressivo que corrobore a suposição de que Sodré teve participação nos programas do PCB (na declaração de março ou mesmo no V Congresso, de 1960). Para o professor José Paulo Netto,

Sodré jamais admitiu essa vinculação, mesmo assumindo-se como marxista, e, na verdade, nunca se identificou com as posturas sectárias e estreitas que o PCB assumiu no período que vai das cassações do seu registro partidário (maio de 1947) e dos mandatos de seus deputados (janeiro de 1948) ao enunciado de sua nova política (“Declaração de março de 1958”). Não há dúvidas, todavia, de que se verifica uma notável congruência entre as concepções defendidas por Sodré, em sua maturidade intelectual, e as proposições políticas do PCB posteriores a 1958; para alguns analistas ${ }^{19}$, Sodré teria sido mesmo um teórico do PCB (NETTO, 2011, p. 25-26).

É basilar frisar que Sodré pôde explicar melhor sua teoria de Brasil porque elaborou investigações profundas sobre a realidade nacional daquele período no momento em que esteve no Iseb. Não podemos conjecturar que programas e resoluções do partido possam se ombrear a uma obra tão abrangente e complexa como a de Sodré corolário de uma investigação profunda sobre o Brasil no período do Iseb. Inegável que Sodré não usa o verbete feudalismo no sentido que ele teve em alguns países da Europa feudal. Segundo João Quartin de Moraes, há uma confusão (de má-fé) semântica:

O uso constante, na obra de Sodré, dessa categoria é claro e coerente: denota as relações de produção baseadas no latifúndio e na dependência pessoal do trabalhador (colonato, parceria e demais formas de produção não baseadas

19 José Paulo Netto se refere à obra Um olhar à esquerda: a utopia tenentista na construção do pensamento marxista de Nelson Werneck Sodré, do cientista político Paulo Ribeiro da Cunha. 
na troca de trabalho vivo por salário), que permitem ao latifundiário extrair rendas pré-capitalistas da terra (MORAES, 2006, p. 159).

A revolução brasileira enfrentaria, naquele contexto, a inevitabilidade de lidar com os grupos atrelados aos enormes "trustes internacionais" e seus agentes internos. Por isso seu caráter anti-imperialista e antifeudal. Para tanto, inexoravelmente, teria de ter um caráter nacional, apoiando-se naqueles setores considerados nacionalistas Sodré entendia ser a burguesia nacional a classe que poderia capitanear esses setores (CAMPOS; VIEIRA, 20I8).

Assim, existia uma questão fulcral a ser resolvida pelos setores de esquerda: suster o desenvolvimento capitalista ou seguir uma orientação de revolução aberta para chegar ao socialismo? Ao final, está a preocupação em explicar: I) a questão da terra; 2) o povo/nação em desenvolvimento; 3) o movimento da revolução burguesa; 4) a via de desenvolvimento capitalista, e 5) a questão da "transição" para o socialismo. Sabemos que essas questões, a despeito de muitas, seguem inconclusas na historiografia e ciências sociais brasileiras e na realidade atual, visto que não foi possível a realização plena da reforma agrária e da democracia no Brasil (LINZ; STEPAN, I999).

\section{CONSIDERAÇÕES FINAIS}

Pressupondo que a leitura da obra de Nelson Werneck Sodré tem sido alvo de incorreções teóricas praticadas pela historiografia brasileira desde a década de 1970, pondera-se a urgência premente de redirecionar o debate, num reajuste de foco, conforme a diligência de balizar e compreender os pressupostos de sua obra. A sua teoria de revolução brasileira teve forte lastro teórico de inspiração marxista (GRESPAN, 2006). Sodré faz parte da tentativa de conhecer o Brasil pela ótica do desenvolvimento e da autonomia nacional e, no Iseb, faz parte daquilo a que José Carlos Reis chamou "os redescobridores" do Brasil (REIS, 2007). Um historiador que escreveu 56 livros "e que produziu por cerca de seis décadas tem, por certo, uma trajetória complexa e dotada de uma particularidade iluminante da própria trajetória do marxismo" (DEL ROIO, 20I6b, p. 85).

Mas não se justifica apenas pela abundância de sua obra, mas sim pela sua rica teoria de Brasil que foi vilipendiada após a contrarrevolução de I964. A tese de Sodré não se limita a "reescrever anedoticamente" a história brasileira. Antes, quer compreender as relações de forças da conjuntura que se configurou no pré-I964. Quer compreender como, dialeticamente, pode-se constituir um povo/nação e se realizar uma mudança social pela via democrática, problemática que, ainda hoje, quando se escreve este paper, assola o país. Sodré reapresenta o problema da dominação imperialista e da autonomia nacional e verifica as tendências históricas de forças para que isso se configure.

A centralidade e o objetivo deste debate foram (e continuam sendo) a análise da categoria de revolução brasileira perpetrada pelo historiador marxista Nelson Werneck Sodré, priorizando sua perspectiva de totalidade histórica e social e reto- 


\section{Estudar a trajetória dos intelectuais não é} uma tarefa fácil. Inseri-los em uma instituição como o Iseb torna-se mais complexo ainda, pois o próprio Sodré, em sua obra Luta pela cultura, evidencia como esse instituto não era homogêneo ideologicamente, mas entrecortado por contradições e transversalidades que desnudavam a realidade nacional daquele período de intensas lutas sociais

mando criticamente as contribuições daquela interpretação da realidade nacional em face da tradição crítico-intelectual que se seguiu após os anos 1960. A tese e os pressupostos metodológicos, seguindo pistas de importantes teóricos da obra de Sodré, como Marcos Del Roio e José Paulo Netto, apontam para a interpretação de que o historiador militar, malgrado "aspectos problemáticos" (NETTO, 2OII, p. 74), construiu uma vigorosa teoria e pode vir a contribuir para as investigações no campo da história brasileira do tempo presente.

Estudar a trajetória dos intelectuais não é uma tarefa fácil. Inseri-los em uma instituição como o Iseb torna-se mais complexo ainda, pois o próprio Sodré, em sua obra Luta pela cultura, evidencia como esse instituto não era homogêneo ideologicamente, mas entrecortado por contradições e transversalidades que desnudavam a realidade nacional daquele período de intensas lutas sociais (SODRÉ, I990a).

Portanto, voltar ao Iseb e a Nelson Werneck Sodré remete-nos ao estudo de uma realidade nacional que ainda, com todos os aspectos problemáticos, lança luz sobre um país que não resolveu seus dramas históricos: note-se que a ameaça à pretensa institucionalidade democrática atual põe a sociedade brasileira em alerta. Concordamos com José Paulo Netto em que a teoria da revolução de Sodré tem problemas, "que não se devem às suas concepções teórico-metodológicas, mas a debilidades e deficiências das bases empíricas sobre as quais ele construiu algumas de suas generalizações" (NETTO, 20II).

É notória e elementar a necessidade de "conhecer e avaliar corretamente a história e as diferentes interpretações da realidade nacional, assim como as diversas teorias elaboradas ao longo do tempo sobre a revolução brasileira" (PERICÁS, 20I9, p. 9o). Por conseguinte, localizar a contribuição de Sodré e de sua teoria de revolução brasileira nesta atual quadra histórica pode, embora talvez não como queira a nossa razão, nos guiar por caminhos que levem à compreensão do Brasil. 
Não foi nossa intenção esgotar o tema da trajetória intelectual de Sodré no Iseb, mesmo porque, como agenda de pesquisa ${ }^{20}$, isso pode levar anos, dada a magnitude do autor e da instituição Iseb. Compreender os nexos causais entre Iseb e intelectuais é uma árdua e laboriosa responsabilidade para qualquer pesquisador da área das ciências humanas - independentemente dos métodos empregados. Assim, como primeira aproximação com a obra de Sodré, produzida por efeito de sua trajetória intelectual e política, pudemos concluir que o debate suscitado naquele momento reverberou fortemente na política nacional e nos rumos do país. O Iseb foi identificado como um epicentro de ideias subversivas e contrárias aos interesses - ironia! nacionais. Por isso, em futura e pretendida pesquisa, queremos investigar as relações entre política e ideologia na fase final do Iseb, antes de seu fechamento pelo golpe burguês-militar, e responder à pergunta: por que as teorias de desenvolvimento nacional produzidas no último Iseb não serviam aos interesses da fração de classe que se tornou hegemônica, tanto que seus intelectuais foram presos e levados a inquéritos policiais militares (IPMs)?

Obviamente, essa já é uma segunda etapa. Primeiro foi necessário localizar a teoria da revolução brasileira que incomodou os setores dominantes tornados hegemônicos. Parecem ser essas perguntas inocentes, mas a pesquisa em fontes e no acervo de Nelson Werneck pode nos ajudar a refinar nosso olhar sobre um campo específico das ciências sociais - o pensamento social — para o entendimento do Brasil.

\footnotetext{
* Doutorando do Programa de Pós-Graduação em Ciências Sociais da Faculdade de Filosofia e Ciências da Universidade Estadual Paulista "Júlio de Mesquita Filho" (FFC-Unesp), campus Marília. Pesquisador, na graduação e no mestrado, da concepção de revolução brasileira segundo o PCB no período 1954-1964. Estudou Ciência Política, em regime de intercâmbio, na Universidade de Santiago de Compostela (USC), Espanha, onde pesquisou o sistema partidário na União Europeia. Professor de Sociologia no ensino regular do estado de São Paulo.
}

Texto recebido em 30 de abril de 2021; aprovado em 16 de maio de 2021.

\footnotetext{
20 A propósito, este artigo é parte integrante de minha tese de doutorado A revolução brasileira na obra de Nelson Werneck Sodré: o Brasil na revolução democrático-burguesa (1961-1964). Por isso, pode até denotar a ideia de "artigo inconcluso", mas, na minha acepção, o artigo científico tem a função de problematizar aspectos de uma pesquisa de escopo maior, que esteja: a) terminada, ou b) em andamento. No caso, a pesquisa está em andamento, e aqui se busca mostrar à comunidade científica uma parte importante dos resultados alcançados.
} 
ARARIPE, Luís de Alencar. Militares e democracia. In: CUNHA, Paulo Ribeiro; CABRAL, Fátima (Org.). Nelson Werneck Sodré: entre o sabre e a pena. São Paulo: Unesp, 2006.

CONTE, Daniela. Nelson Werneck Sodré e as interpretações do Brasil moderno (1958-1964): análise de conceitos e contexto de um intelectual brasileiro. Orientadora: Claudia Wasserman. 2010. 144 f. Dissertação (Mestrado em História) — Instituto de Filosofia e Ciências Humanas, Universidade Federal do Rio Grande do Sul, Porto Alegre, 2010.

BANDEIRA, Luiz Alberto Moniz. O governo João Goulart: as lutas sociais no Brasil, 1961-1964. 8. ed. São Paulo: Editora Unesp, 2010.

BIELSCHOWSKY, Ricardo. Ignácio Rangel. In: PERICÁS, Luiz Bernardo; SECCO, Lincoln. Intérpretes do Brasil: clássicos, rebeldes e renegados. São Paulo: Boitempo, 2014.

BRESSER-PEREIRA, Luiz Carlos. O conceito de desenvolvimento do Iseb rediscutido. Dados, Rio de Janeiro, v. 47, n. 1, p. 49-84, 2004.

CUNHA, Paulo Ribeiro. Militares e militância: uma relação dialeticamente conflituosa. 2. ed. São Paulo: Editora Unesp, 2020.

O antimil: o setor militar — origens de uma organização. In: Lutas Sociais, São Paulo, n. 29, p. 59-71, jul.-dez. 2012.

2006.

; CABRAL, Fátima (Org.). Nelson Werneck Sodré: entre o sabre e a pena. São Paulo: Unesp,

DEL ROIO, Marcos. Capitalismo e revolução em Caio Prado Júnior. Lutas Sociais, São Paulo, v. 20, p. 10-23, jan.-jun. 2016 a.

Sodré e a dialética da formação social brasileira. Crítica Marxista, n. 42, p. 85-102, 2016b.

FERRARI, Márcio. O peso da sociedade. Pesquisa Fapesp, São Paulo, ed. esp., p. 64-67, dez. 2014.

GORENDER, Jacob. O escravismo colonial. São Paulo: Ática, 1978.

GRESPAN, Jorge. O conceito de "modo de produção" em Nelson Werneck Sodré. In: CUNHA, Paulo Ribeiro; CABRAL, Fátima (Org.). Nelson Werneck Sodré: entre o sabre e a pena. São Paulo: Unesp, 2006.

JOHNSON, Allan. Mudança social. In: Dicionário de sociologia. Rio de Janeiro: Zahar, 1997.

LINZ, Juan J.; STEPAN, Alfred. A transição e consolidação da democracia: a experiência do sul da Europa e da América do Sul. São Paulo: Paz e Terra, 1999.

LOVATTO, Angélica. O pensamento de Nelson Werneck Sodré nos Cadernos do Povo Brasileiro In: CUNHA, Paulo Ribeiro; CABRAL, Fátima (Org.). Nelson Werneck Sodré: entre o sabre e a pena. São Paulo: Unesp, 2006.

Os Cadernos do Povo Brasileiro e o debate nacionalista dos anos 1960: um projeto de revolução brasileira. 2010. 386f. Tese (Doutorado em Ciências Sociais) — Pontifícia Universidade Católica de São Paulo, São Paulo, 2010.

MARTINS, Luciano. Aspectos políticos da revolução brasileira. Revista Civilização Brasileira, n. 2, p. 15-34, maio 1965.

MARX, Karl. Contribuição à crítica da economia política. São Paulo: Expressão Popular, 2008.

Formações econômicas pré-capitalistas. São Paulo: Paz e Terra, 1985.

Manuscritos econômico-filosóficos. São Paulo: Boitempo, 2010.

ENGELS, Friedrich. O manifesto comunista. 20. ed. Tradução Maria Lucia Cumo. São Paulo: Paz e Terra, 2010.

MAZZEO. Antonio Carlos. Estado e burguesia no Brasil: origens da autocracia burguesa. 3. ed. São Paulo: Boitempo, 2015.

MILLS, Wright C. A imaginação sociológica. 2. ed. Rio de Janeiro: Zahar, 1969. 
MIRANDO, Orlando (Org.); FERNANDES, Florestan (Coord.). Trótski: Política. São Paulo: Ática, 1981. (Coleção Grandes Cientistas Sociais, v. 22).

MORAES, João Quartim de. O programa nacional-democrático: fundamentos e permanência. In: MORAES, João Quartim; DEL ROIO, Marcos (Org.). História do marxismo no Brasil: visões do Brasil. Campinas: Editora Unicamp, 2007. v. 4.

MORAES, João Quartim de. Sodré, Caio Prado e a luta pela terra. In: CUNHA, Paulo Ribeiro; CABRAL, Fátima (Org.). Nelson Werneck Sodré: entre o sabre e a pena. São Paulo: Editora Unesp, 2006.

NETTO, José Paulo. Nelson Werneck Sodré: o general da história e da cultura. São Paulo: Expressão Popular, 2011.

PÉCAUT, Daniel. Intelectuais e a política no Brasil: entre o povo e a nação. São Paulo: Ática, 1990.

PERICÁS, Luiz Bernardo (Org.). Caio Prado Júnior: uma biografia política. São Paulo: Boitempo, 2016.

Caminhos da revolução brasileira. São Paulo: Boitempo, 2019.

PINTO, João Alberto Costa. O percurso intelectual de Nelson Werneck Sodré, historiador do Brasil: 1911-1999. Revista de Historia Actual, Cádiz, v. 9, n. 9, p. 169-180, 2011. Disponível em: <http://marxismo21.org/wp-content/uploads/2012/09/Artigo-sobre-Sodr\%C3\%A9-Jo\%C3\%A3o-Alberto-Revista-Hist\%C3\%B3ria-Actual.pdf>. Acesso em: 15 abr. 2021.

PRADO JÚNIOR, Caio. A revolução brasileira. In: FLORESTAN, Fernandes. O que é revolução?. 2. ed. São Paulo: Expressão Popular, 2012.

RECKZIEGEL, Ana Luiza Setti. Nelson Werneck Sodré. In: AXT, Gunter; SCHÜLER, Fernando Luís. Intérpretes do Brasil: ensaios de cultura e identidade. Porto Alegre: Artes e Ofícios, 2004. p. 315332.

REIS, José Carlos. As identidades do Brasil: de Varnhagen a FHC. Rio de Janeiro: Editora FGV, 2007.

SILVA, Lígia Osório. A "herança colonial" e as lições da história em Nelson Werneck Sodré. In: CUNHA, Paulo Ribeiro; CABRAL, Fátima (Org.). Nelson Werneck Sodré: Entre o Sabre e a Pena. São Paulo: Unesp, 2006.

SIRINELLI, Jean-François. Os intelectuais. In: RÉMOND, René. Por uma história política. 2. ed. Rio de Janeiro: FGV, 2003.

SKIDMORE, Thomas. Brasil: de Getúlio a Castelo. 6. ed. São Paulo: Paz e Terra, 1979.

SODRÉ, Nelson Werneck. A luta pela cultura. Rio de Janeiro: Bertrand Brasil, 1990a.

Capitalismo e revolução burguesa no Brasil. Belo Horizonte: Oficina de Livros, 1990b.

Formação histórica do Brasil. 14. ed. Rio de Janeiro: Graphia, 2002. (Coleção Memória Brasileira, v. 6).

História da burguesia brasileira. Rio de Janeiro. Civilização Brasileira, 1964.

Introdução à revolução brasileira. Rio de Janeiro: José Olympio, 1958.

Memórias de um escritor. Rio de Janeiro: Civilização Brasileira, 1970. v. 1.

SODRÉ, Olga. O Iseb, Nelson Werneck Sodré e a cultura brasileira: um testemunho histórico. Albuquerque: Revista de História, Campo Grande, v. 3, n. 6, p. 9-21, jul.-dez. 2011.

TOLEDO, Caio Navarro de. Iseb: fábrica de ideologias. 2. ed. São Paulo: Ática, 1982.

VIEIRA, Carlos Alberto C.; CAMPOS, Fábio Antonio de. Imperialismo e questão nacional em Nelson Werneck Sodré. Texto para Discussão, n. 345. Campinas: IE-Unicamp, ago. 2018. 